Research Article

\title{
The Phytochemical Screening and Antioxidants Potential of Schoenoplectus triqueter L. Palla
}

\author{
Amir Hassan (D, Zakaria Akmal, and Nawaz Khan (D) \\ Department of Chemistry Government Post Graduate College Mardan, Abdul Wali Khan University, Mardan 2300, \\ Khyber Pakhtunkhwa, Pakistan \\ Correspondence should be addressed to Amir Hassan; amirhassan741@gmail.com
}

Received 5 March 2020; Revised 9 June 2020; Accepted 23 June 2020; Published 30 September 2020

Guest Editor: Yunus Alparslan

Copyright (C) 2020 Amir Hassan et al. This is an open access article distributed under the Creative Commons Attribution License, which permits unrestricted use, distribution, and reproduction in any medium, provided the original work is properly cited.

Over the centuries, humans use different types of therapeutic plants to treat several diseases. Cyperaceae family has a significant number of monocotyledon plants, and Schoenoplectus is one of the genera that belong to this family; about forty-nine compounds are isolated. Our current study was evaluated on Schoenoplectus triqueter L. Palla to show the potential of its antioxidants and confirm the phytochemical constituents in this plant species. Fully powdered plant taken for successive extraction process in hot continuous process for Soxhlet was $20 \mathrm{~g}$ plant in porous bag manually prepared; the constant temperature provided was $40-50^{\circ} \mathrm{C}$. In the maceration extraction method, $30 \mathrm{~g}$ plant was taken in a closed jar and the solvent placed for extraction was $300 \mathrm{~mL}$ of ethanol; the extract gets filtered and fractioned to different solvents such as water, dichloromethane, ethyl acetate, and $n$-hexane fraction. Important types of phytochemicals found in this species are alkaloids, proteins, amino acids, flavonoids, phenols, terpenoids, tannins, saponins, and carbohydrates. All the entire extracted fractions which are water, dichloromethane, ethyl acetate, and n-hexane possess noticeable activity at various concentrations of $31.25,62.5,125,250$, and $500 \mu \mathrm{g} / \mathrm{mL}$ by the dilution method. The ethyl acetate extract holds greater median inhibitory concentration $\left(\mathrm{IC}_{50}=3.52 \pm 0.01\right)$, and water showed $\mathrm{IC}_{50}=3.61 \pm 0.01$ percent potential as compared to the standard ascorbic acid which possesses $\mathrm{IC}_{50}=2.27 \pm 0.01$. Their potential may be enhanced or lowered with the purification of extracts which might be useful in biological activities.

\section{Introduction}

Over the centuries, humans use different types of therapeutic plants to treat or cure diseases. Such therapeutic plants are very important and play a key role in a better and happy life, for health at every stage [1]. Cyperaceae family has a significant number of monocotyledon plants but the taxonomist did not give proper attention to this family [2]. The family Cyperaceae mostly contain halophytic plants and most of them are fibrous and found in Pakistan [3]. Schoenoplectus is one of the genera that belong to this family; about forty-nine compounds are isolated from the plant Schoenoplectus lacustris in alcohol fraction and water fraction; all the compounds are applied one by one to green algae, i.e., Selenastrum capricornutum (a unicellular organism that is normally used in tests of toxicity as a bioindicator of eutrophic spots) in such a way to test the phytotoxic effect of all forty-nine compounds which are isolated from the Schoenoplectus lacustris. Out of all the most active compounds is (negative) catechin displaying similar inhibition to the algaecide copper sulphate [4]. There is no such a presence of any antifungal compound in S. triqueter because it does not inhibit many fungi such as (a) Pestalotia palmarum Cooke., (b) hylotialateripes (Ellis \& Ev) Guba, and (c) Polyschema olivacea (Ellis \& Everh.) while it acts as a host for the abovementioned fungi [5]. Batool and Hameed reported three different species from the Cyperaceae family collected from different areas of Punjab. All the species were introduced to salt stress; under very crucial and high saline conditions, the $S$. triqueter showed high advanced root adaptation [6]. Fy et al. examine the basic species of Schoenoplectus from the midway river with the help of APLG fingerprint. Among the species, the S. lacustris is dominant in all hybrids which are studied from all rivers and 
the additivity was proved among the fingerprints of $S$. triqueter [7]. Jiménez-Mejías et al. reported that in Pakistan, India, and Africa, Schoenoplectus corymbosus (Cyperaceae) is widely distributed. Its presence in the wetland of Morocco and Spain is proved recently. We know the availability of this plant in the extreme of the Mediterranean. Since 1999, it has not been collected due to its medium-large size [8]. Roalson studied the vast variation in the chromosome number of family Cyperaceae among the genera. Recently, studies indicate that there are 4231 chromosomes in this family. About $16 \%$ of species recently have been known/recognized [9]. Antioxidants are those substances that prevent most of the oxidation reactions which are initiated with the production of free radicals. Antioxidants captured free radicals thereby delaying or preventing damage to the cells and tissues of the living organisms. Antioxidants are also called reducing agents [10-12]. Antioxidants have also a lot of applications on an industrial level such as preservation of food, cosmetics, and prevention of gasoline and rubber degradation. Various rich sources of antioxidant compounds such as carotenoids, flavonoids, lutein, and polyphenols are vegetables and fruits [13, 14]; plant extraction or isolation produces some potent compounds or substances that are accountable for biological activity [15]. Modern medicine, food supplements, and folk and traditional medicine are mainly obtained from plants [16]. In medicinal plants, important constituents such as vitamins A, C, and E, flavonoids, lignins, and tannins which are phenolic compounds are found and represent antioxidant potentials [17]. Our current study evaluated the extraction and fractionation of Schoenoplectus triqueter L. Palla plant, performed in vitro antioxidants 1,1-diphenyl-2-picrylhydrazyl (DPPH) radical scavenging potential, and confirmed the phytochemical constituents.

\section{Materials and Methods}

The present study was conducted to determine the in vitro antioxidant potential and phytochemicals screening of the species Schoenoplectus triqueter (L.) Palla from the genera Schoenoplectus. The plant S. triqueter was identified by a botanical export Professor Muhammad Israr of Botany Department, Government Post Graduate College, Mardan 23200, KP, Pakistan, and was also confirmed through various literature studies and comparison data obtained from different floras.

2.1. Plant Collection and Drying. The given plant was collected during the month of January-February winter season at Katlang from river areas: geographical location: Mardan, KP, Pakistan, Asia, and geographical coordinates: $34^{\circ} 21^{\prime} 38^{\prime \prime}$ North, $72^{\circ} 4^{\prime} 49^{\prime \prime}$ East. Only a healthy stem part of the plant was collected and washed with sterilized water to remove any surface dust and contaminants. The collected plants were stored under shades and protected from light exposure and contaminants in the class store for three weeks to completely dry under room temperature and humidity. After drying, they were then ground with a normal grinder, and a fully powdered sample was obtained with a greater surface area for a better extraction process.

2.2. Soxhlet Extraction. The fully powdered plant taken for the successive extraction process in hot continuous process for Soxhlet [18] was $20 \mathrm{~g}$ plant in porous bag manually prepared from the sterilized filter paper. In the round bottom flask of Soxhlet was taken $250 \mathrm{~mL}$ of ethanol, and a manually prepared cellulose bag was placed in the thimble chamber of Soxhlet. The upper part was fitted with a condenser where cool water inflow and outflow were provided for liquid condensation throughout the process of successive extraction. All the apparatus was fitted over the Mantoux heater at a constant temperature of $40-50^{\circ} \mathrm{C}$. The process continued until the liquid droplet from the siphon arm does not leave any residues during the cycling. The extract was obtained and then filtered and fractioned after a controllable water bath to water, dichloromethane, ethyl acetate, and $n$ hexane fraction. The dried fraction was then evaluated for further analysis.

2.3. Maceration Extraction. In the maceration extraction [18] method, the $30 \mathrm{~g}$ plant was taken in a closed jar made from Pyrex glass. The solvent placed for extraction was ethanol $300 \mathrm{~mL}$. The jar with a closed cap was placed under the shade at room temperature for 30 days only. At least twice and trice a day, the plant was shaken with continuous stirring to dissolve the plant sample and release the soluble metabolites to the solvent. After that, the extract was then filtered and dried under a controllable water bath and then fractioned to different solvents such as water, dichloromethane, ethyl acetate, and $n$-hexane fraction. The dried fraction was then evaluated for further analysis.

2.4. Phytochemical Screening. The medicinal plants contain some important types of biologically active compounds called phytochemicals which are accountable and show potency towards the biological activity. Their confirmations, identifications, and characterization are very important, and to detect these phytochemicals, a standard procedure previously reported in [19-22] was followed as given hereinafter.

2.4.1. Carbohydrates and Tannins. Aqueous extract $(2.5 \mathrm{~mL})$ in a test tube was treated with a Molisch reagent $(0.5 \mathrm{~mL})$ followed by 3 drops of concentrated $\mathrm{H}_{2} \mathrm{SO}_{4}$; a violet ring showed the presence of carbohydrates. While treating with ferric chloride $(0.5 \mathrm{~mL})$ solution, green color in a condensed form showed tannins.

2.4.2. Alkaloids and Saponins. Fresh dilute acidic extracts $(\mathrm{HCl})(2.5 \mathrm{~mL})$ added were treated with reagents (Wagner, Hager, and Mayer's) $(0.5 \mathrm{~mL})$; color precipitation in solution showed positive results for alkaloids. Aqueous extract $(4 \mathrm{~mL})$ vigorously in the test tube was shaken for 2 minutes; a froth of about $5 \mathrm{~cm}$ formed in about 10 minutes showed saponins. 
2.4.3. Flavonoids. Acidic extracts $(\mathrm{HCl})(2.5 \mathrm{~mL})$ were added to two test tubes; sodium hydroxide $(\mathrm{NaOH})(1.5 \mathrm{~mL})$ was added to one tube and $1.5 \mathrm{~mL}$ of distilled water was added to the other one; yellow color confirmed flavonoids. While treating with lead acetate $(1.5 \mathrm{~mL})$, yellowish precipitate also showed flavonoids.

2.4.4. Sterols and Triterpenes. Salkowski. While $2.5 \mathrm{~mL}$ of ethanolic extract was directly treated in a test tube with the addition of 3 drops of concentrated sulphuric acid $\left(\mathrm{H}_{2} \mathrm{SO}_{4}\right)$, reddish-brown color with an absence of green layer showed positive results. Lieberman. $2.5 \mathrm{~mL}$ of fresh ethanolic extract in a test tube was treated with $0.5 \mathrm{~mL}$ of acetic anhydride and also the addition of 3 drops of concentrated sulphuric acid $\left(\mathrm{H}_{2} \mathrm{SO}_{4}\right)$, and the appearance of brown-reddish color at the upper layer showed a positive result.

2.4.5. Anthraquinone Glycosides and Resin. Fresh ethanolic extract $(2.5 \mathrm{~mL})$ was mixed with an ammonia solution $(0.5 \mathrm{~mL})$ in a test tube, and a combination of light rose color with more green color indicates a positive result of anthraquinone glycosides. While $2.5 \mathrm{~mL}$ of water extract was treated with $1: 1$ (water and acetone), no turbidity indicates the absence of resin.

2.4.6. Proteins and Amino Acids. Xanthoproteic. $2.5 \mathrm{~mL}$ of the extract was directly treated with 3 drops of concentrated nitric acid $\left(\mathrm{HNO}_{3}\right)$ in a test tube, and yellow color indicates the protein-positive result. Biuret. $4 \mathrm{~mL}$ of the extract in a test tube followed by sodium hydroxide $\mathrm{NaOH}(10 \%)$ and $1 \mathrm{~mL}$ was heated and treated with copper sulphate $\left(\mathrm{CuSO}_{4}\right)$ $(10 \%)$, and $0.5 \mathrm{~mL}$ solution indicates protein-positive results.

2.4.7. Diterpene Fats and Fixed Oils. $4 \mathrm{~mL}$ of the extract in a test tube was treated with 3 drops of copper acetate solution, and bright green color appearance indicates diterpenes positive result. While pressing $3 \mathrm{~mL}$ of water extract within filter paper, no stain of oil was formed or seen which showed a positive result and absence of fixed oils and fats.

2.4.8. Phenol Content Determination. The total phenol content in aqueous extraction and in other different fractions of $S$. triqueter was mainly obtained on the basis of the last-mentioned described procedure [23]. After this, $2.5 \mathrm{~mL}$ of $10 \%$ Folin-Ciocalteau's reagent was mixed with about $2 \mathrm{~mL}$ of $2 \%$ sodium carbonate solution $\left(\mathrm{Na}_{2} \mathrm{CO}_{3}\right)$, along with the addition of $0.5 \mathrm{~mL}$ of aqueous extract and some amount of $S$. triqueter $(1 \mathrm{mg} / \mathrm{mL})$; the above mixture is placed in an incubator machine for at least 15 minutes at $45^{\circ} \mathrm{C}$; at $765 \mathrm{~nm}$, the absorbance of the mixture takes place. The identification of quantity was done with respect to the standard of gallic acid at various concentrations $(1,0.5,0.25,0.125,0.063$, and $0.031 \mathrm{mg} / \mathrm{mL}$ ). The content of the total phenolic compounds was calculated based on a standard curve prepared using gallic acid and expressed as milligrams of gallic acid equivalent (GAE) per gram of sample.
2.4.9. Flavonoid Content Determination. By using aluminum chloride with the help of the colorimetric method, the total flavonoid content was obtained [24]. In such a method, about $1 \mathrm{~mL}$ of crude extract fractions of $S$. triqueter was added to $3 \mathrm{~mL}$ solution of methanol, followed by the addition of $0.2 \mathrm{~mL}$ of $10 \%$ aluminum chloride $\left(\mathrm{AlCl}_{3}\right)$, about $0.2 \mathrm{~mL}$ of potassium acetate $(1 \mathrm{M})$, and $5.6 \mathrm{~mL}$ of distilled water, and then left at room temperature for at least $35 \mathrm{~min}$. Absorbance takes place at $420 \mathrm{~nm}$. Here, the quantification was done with respect to the standard of gallic acid at various concentrations $(1,0.5,0.25,0.125,0.063$, and $0.031 \mathrm{mg} / \mathrm{mL})$; again, the total phenolic content was calculated based on a standard curve prepared using gallic acid and expressed as milligrams of gallic acid equivalent (GAE) per gram of sample.

2.5. Antioxidant Activity. The antioxidant activity was performed according to the previously reported one in [25-28] using a stable DPPH (1,1-diphenyl-2-picrylhydrazyl) free radical scavenging power assay for all the entire fraction extracts such as $n$-hexane, water, dichloromethane, and ethyl acetate. All the extracts were first dissolved in suitable solvent dimethylsulfoxide (DMSO) at various concentrations of $31.25,62.5,125,250$, and $500 \mu \mathrm{g} / \mathrm{mL}$ by dilution method. Before at least $2 \mathrm{hrs}, 0.0238$ grams of solid DPPH was taken by weight in $100 \mathrm{~mL}$ of methanol solvent, and the standard solution was covered with aluminum foil in the dark at room temperature to avoid light decomposition. First, all the entire fraction concentration was mixed with DPPH solution sample extracts $(10 \mu \mathrm{L})$ and standard solution $(90 \mu \mathrm{L})$ stored for incubation for 30 minutes at $37^{\circ} \mathrm{C}$ in the dark. Then, at $517 \mathrm{~nm}$ of wavelength, absorbance was measured at least three times. The positive control media were treated the same as sample extracts with DPPH; in negative cases, DMSO was placed. The spectrophotometer was used to measure the absorbance, and the percentage of $\mathrm{DPPH}$ free radical scavenging activity was calculated according to the equation of $[29,30]$, where $Y^{\prime}$ is the absorbance of sample extracts and $X^{\prime}$ is actually the standard sample absorbance:

$$
\text { DPPH \% scavenging activity }=\frac{X^{\prime}-Y^{\prime}}{X^{\prime}} \times 100 .
$$

2.6. Statistical Analysis. All the data were calculated in triplicate as a standard \pm mean using test statistics and standard deviation. The latest Graph pad prism software was used for the evaluations of the median inhibitory concentration values in spite of the statistical regression and correlation analysis.

\section{Results and Discussion}

3.1. Phytochemical Screening. All the important phytochemicals were confirmed and predicated in this species according to the previous methods in [19-22]. The most important types of phytochemicals found in this species are alkaloids, proteins, amino acids, flavonoids, phenols, 
terpenoids, tannins, saponins, carbohydrates, etc. positively detected during phytochemical confirmation as shown in Table 1. Each phytochemical showed potency towards some biological action; for example, flavonoids play a role in antioxidant potential [31]; alkaloids are important in antimicrobial, analgesic, and other antispasmodic actions [31-33] and inflammatory potency was found with steroids [32]. According to [34-38], plants contain phytochemicals which were purified and mainly used to treat some types of health-related diseases and also utilized in making dietary supplement and nutrients. Each phytochemical shows novel biological behavior which may increase the chances of the discovery of new compounds like antibiotics against pathogens $[18,39-41]$ and only the flavonoids which are polyphenols and play a role in antibiotics activity $[42,43]$ because flavonoids make complexes with bacterial proteins, cell wall, and other ingredients which are accountable for biological action [44]. Also, many other compounds such as terpenoids, tannins, steroids, and saponins also show the plants' potential towards antimicrobial (both bacterial and fungus) activity [45]. Steroids make the lipid-bilayer membrane rupture and release liposome [46] while saponins from the cell of microbes release enzymatic protein [47] and terpenoids are involved in the weakening of cell wall and tissue of the microorganisms [48].

The flavonoids and phenolic content were determined by the Folin Ciocalteu method and the phenol content was quantitatively estimated and ranged from $5.33 \pm 0.05$ to $16.45 \pm 0.02$ (mg 55GAE/g) as shown in Table 2. The entire fraction contained an appreciable amount of phenolic content; the water fraction possesses noticeable greater content as compared to ethyl acetate fraction while other fractions such as $n$-hexane and DCM possess lower content of phenol. In the determination of flavonoid content, water fraction was found dominant among all other fractions and ranged from $3.73 \pm 0.02$ to $14.05 \pm 0.5$ (mg GAE/g); the $n$ hexane contained the least amount of flavonoid content as shown in Table 2.

Plant tissues are a rich source of phenolic compounds and are used as antioxidants. This antioxidant activity is good and effective for some diseases [49], because of the presence of hydroxyl groups, which play an important role in their scavenging ability. Thus, they have the ability to react with active oxygen radicals such as hydroxyl radicals [50]. Flavonoids are polyphenolic compounds, contain many phenolic groups, and are responsible for some of the health benefits of vegetables and fruits [51]. They are known to play an active role in the quenching of free radicals, in other words, to trap the free radicals to avoid any harm, because of their redox properties [52]. Tannins, however, are high molecular weight polyphenolic compounds that have also the best property and used as antioxidants [53].

3.2. Antioxidant Activity. The S. triqueter L. Palla plant antioxidant potential was performed and calculated via a standard protocol of [25-27] to check whether the fractions of this plant possess free radicals to destroy the effects and oxidative stress to keep the organisms safe [54].
Table 1: Phytochemical screening test results of S. triqueter L. Palla.

\begin{tabular}{lcc}
\hline Serial no. & Phytochemical tested & Test results \\
\hline 1 & Alkaloids & + \\
2 & Flavonoids & + \\
3 & Saponins & + \\
4 & Protein and amino acids & + \\
5 & Fats and oil & - \\
6 & Tannins & + \\
7 & Sterol & - \\
8 & Terpenoids & + \\
9 & Glycosides and anthraquinone & + \\
10 & Resin test & - \\
11 & Carbohydrates & + \\
12 & Phenol & + \\
\hline
\end{tabular}

$+=$ Positive means present, $-=$ Negative means absent.

All the entire extracted fractions such as water, dichloromethane, ethyl acetate, and $n$-hexane possess noticeable activity as shown in Table 3 at various concentrations of $31.25,62.5,125,250$, and $500 \mu \mathrm{g} / \mathrm{mL}$ by the dilution method. The ethyl acetate extract possesses greater median inhibitory concentration $\left(\mathrm{IC}_{50}=3.52 \pm 0.01\right)$ and water showed $\mathrm{IC}_{50}=3.61 \pm 0.01$ percent potential as compared to the standard ascorbic acid which possesses $\mathrm{IC}_{50}=2.27 \pm 0.01$. The sample extracts are nearly closed to the standard in the activity of free radicals as shown in Figure 1. All the other relative fractions of $S$. triqueter showed wide ranges of antioxidant activity which were measured as mean and standard deviation taken in triplicate noting that DCM possesses $\mathrm{IC}_{50}=4.05 \pm 0.2$ while $n$-hexane showed $\mathrm{IC}_{50}=6.35 \pm 0.05$; this experimental study and $[20,55]$ have similar results. Elufioye et al. reported that ethyl acetate fraction had the highest DPPH radical scavenging activity, with a concentration providing $50 \%$ inhibition $\left(\mathrm{IC}_{50}\right.$ ) of $0.079 \mathrm{mg} /$ $\mathrm{mL}$ [56]; among all fractions, ethyl acetate fraction exhibits the most potent scavenging activity at $0.5 \mathrm{mg} / \mathrm{mL}$ concentration. In comparison with other fractions, hexane has exhibited the second most potent in percent of inhibition at $0.5 \mathrm{mg} / \mathrm{mL}$ concentration [57]. In [19], the highest antioxidant activity was reported in ethyl acetate extract $\left(\mathrm{IC}_{50}=7.59 \mu \mathrm{g} \mathrm{mL}^{-1}\right)$ followed by ethanol extract $\left(\mathrm{IC}_{50}=74.80 \mu \mathrm{g} \mathrm{mL}^{-1}\right)$ and hexane extract $\left(\mathrm{IC}_{50}=189.89 \mu \mathrm{g} \mathrm{mL}^{-1}\right)$, and also Al-Muniri and Hossain [58] showed that the highest $\mathrm{IC}_{50}$ was found in the order of activity as chloroform >ethyl acetate >hexane >water $>$ methanol $>$ butanol extract. In [59], from the results of antioxidant assays in vitro, ethyl acetate was found to have the highest antioxidant activity. The 50\% inhibition of $\mathrm{DPPH}$ radical scavenging effect $\left(\mathrm{IC}_{50}\right)$ was recorded as $8.67,0.64,0.31$, and $0.14 \mathrm{mg} / \mathrm{ml}$ for the hexane fraction, ethyl acetate fraction, and ethanol fraction; in $[22,60]$, the water extract has the highest scavenging activity among all extracts. Khan et al. [30] revealed that the ethyl acetate fractions of E. gerardiana (root and stem) have significant free radical scavenging potential with values of $2.96 \pm 0.39$ and $2.73 \pm 0.84$. The lowest antioxidant activity was found in the $n$-hexane extract of the plant selected to be equivalent to DPPH $[21,61]$. Free radicals contain single 
TABLE 2: Determination of flavonoids and phenolic contents in S. triqueter.

\begin{tabular}{lcccc}
\hline Contents & Water & DCM & Ethyl acetate & $n$-hexane \\
\hline Total flavonoids (mg GAE/g) & $14.05 \pm 0.5$ & $8.16 \pm 0.02$ & $9.01 \pm 0.005$ & $3.73 \pm 0.02$ \\
Total phenolic (mg GAE/g) & $16.45 \pm 0.02$ & $10.01 \pm 0.01$ & $14.15 \pm 0.01$ & $5.33 \pm 0.05$ \\
\hline
\end{tabular}

TABLE 3: DPPH activity results of different fractions of S. triqueter plant.

\begin{tabular}{lcc}
\hline S. No & Samples extracts & $\mathrm{IC}_{50} \mathrm{mg} / \mathrm{mL}$ \\
\hline 1 & Water fraction & $3.61 \pm 0.01$ \\
2 & Ethyl acetate fraction & $3.52 \pm 0.01$ \\
3 & n-Hexane fraction & $6.35 \pm 0.05$ \\
4 & DCM fraction & $4.05 \pm 0.2$ \\
5 & Control ascorbic acid & $2.27 \pm 0.01$ \\
\hline
\end{tabular}

The data were represented as mean via statistics as a standard deviation (SD) in triplicate under standard graph pad prism software (mean \pm SD). The median inhibitory concentration plotted concentration with percent inhibition.

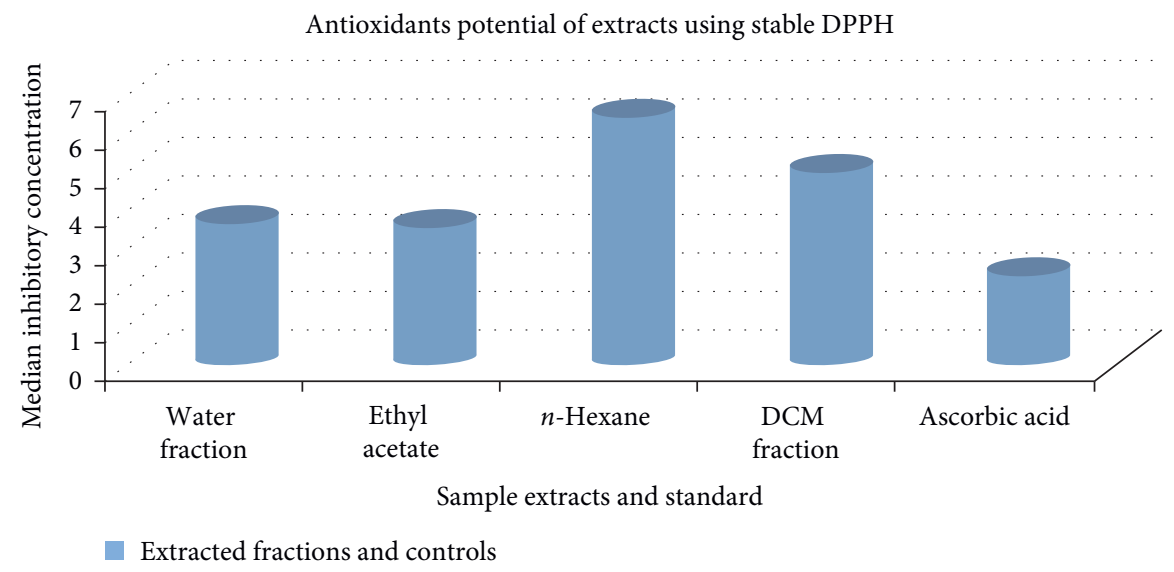

FIGURE 1: Comparisons of 50\% inhibition of plant fractions and standard.

electron, which is produced by the broken down covalent bond between two entities because single electron free radical is too much unstable. The free radical containing oxygen is known as reactive oxygen species (ROS). Reactive oxygen species are also called active oxygen species because the oxygen containing species such as hydroxyl radicals $\left(\mathrm{OH}^{\bullet}\right)$ and superoxide ions $\left(\mathrm{O}_{2}{ }^{\bullet-}\right)$ contains free radicals. Free radicals are formed generally during metabolic processes such as eating and breathing [62-64].

Antioxidants are mostly used for the protection of various diseases such as coronary heart disease, dementia, cancer, Alzheimer's disease, and arthritis [10-12]. Antioxidants have also a lot of applications on an industrial level such as preservation of food, cosmetics, and prevention of gasoline and rubber degradation. Various rich sources of antioxidant compounds such as carotenoids, flavonoids, lutein, and polyphenols are vegetables and fruits $[13,14]$. It has been reported that synthetic antioxidants have high risks of side effects [65]; therefore, proper attention was given towards natural antioxidants. Interrogation on identifying natural antioxidants has become an important problem [66]. In the last few years, natural antioxidants are considered as a good preventive medicine [67]. Plants are the rich source of antioxidants, and every year, thousands of new antioxidant compounds have been invented. Plants are considered as a potential source of new compounds having antioxidant properties $[63,68,69]$. A stable free radical such as the compound of diphenyl picrylhydrazyl is demonstrated by the goodness of the delocalization of the free electrons over the whole molecule. A deep violet color appeared as a result of delocalization by the absorption band in the solution of methanol at about $517 \mathrm{~nm}$. The substance that can donate a hydrogen atom is mixed with the DPPH solution; then, it gives the reduced form with a vanished violet color. In the end, pale color is indicated due to the presence of picryl residue [70-73].

Most of the bioactivities of these crude extracts especially high flavonoids and phenolic content are important. Flavonoids are good and highly effective scavengers for most of the oxidizing compounds such as singlet oxygen, and various types of other free radicals are implicated or involved in several diseases [74]. Flavonoids suppress reactive oxygen formation; in free radical production, chelate elements are specially used, and scavenge reactive species upregulate and protect antioxidant defenses [75]. Similarly, phenolic compounds confer oxidative stress tolerance in plants. Such types of crude extracts of fruits, herbs, vegetables, cereals, and other plant materials are fulfilled by phenolic contents which are highly used in the food industry and medicine industry for their antioxidative properties and for better 
health. It is concluded that their potential towards a stable $\mathrm{DPPH}$ is because they contain flavonoids that are accountable for antioxidants potential.

\section{Conclusion}

It is concluded that $S$. triqueter plant contains almost all important types of phytochemical constituents and possesses antioxidant potential at various concentrations. The ethyl acetate and water fraction extracts had very high antioxidant activity, subsequently. Extracted fraction possesses the antioxidant potential and might be helpful in preventing or slowing the progress of various oxidative stresses. Further study and analysis are strongly recommended to isolate and purify the major phenolic compound as well as other bioactive compounds for further bioactivity tests which are mediated by free radicals; the isolation and identification of antioxidant component in the plant may lead to chemical entities with more potential for clinical use.

\section{Data Availability}

All the data used to support the findings of this study are included within the article.

\section{Conflicts of Interest}

The authors declare that they have no conflicts of interest.

\section{Acknowledgments}

All the authors thank Amir Hassan of the Chemistry Department, Government Post Graduate College, Mardan 23200, Khyber Pakhtunkhwa, Pakistan, for writing, designing, and publishing the manuscript. They also acknowledge Himayat Ullah for project assessment and evaluation.

\section{References}

[1] C. P. Dabanka, "Antibacterial activity of phyllanthusamarus (schumand thonn) extract against salmonella typhicausative agent of typhoid fever," M.S. thesis, Kwame Nkrumah University of Science and Technology, Kumasi, Ghana, 2013.

[2] B. Sanyal and A. Sharma, "Cytological studies in Indian Cyperaceae," Cytologia, vol. 37, no. 1, pp. 13-32, 1972.

[3] M. Qasim, S. Gulzar, and M. A. Khan, "Halophytes as medicinal plants," in Proceedings of the NAM Meeting, Denizli, Turkey, 2011.

[4] B. D'abrosca, M. Dellagreca, A. Fiorentino, M. Isidori, P. Monaco, and S. Pacifico, "Chemical constituents of the aquatic plant Schoenoplectus lacustris: evaluation of phytotoxic effects on the green alga Selenastrum capricornutum," Journal of Chemical Ecology, vol. 32, no. 1, pp. 81-96, 2006.

[5] C.-G. Wu, H.-Y. Tseng, and Z.-C. Chen, "Fungi inhabiting on Schoenpplectus triqueter (L.) palla (I)," Taiwania, vol. 27, no. 1, pp. 35-38, 1982.

[6] R. Batool and M. Hameed, "Root structural modifications in three Schoenoplectus (Reichenb.) Palla species for salt tolerance," Pakistan Journal of Botany, vol. 45, no. 6, pp. 19691974, 2013.
[7] M. Fay, R. Cowan, and D. Simpson, "Hybridisation between Schoenoplectus tabernaemontani and S. Triqueter (Cyperaceae) in the British isles," Watsonia, vol. 24, no. 3, pp. 433-442, 2003.

[8] P. Jiménez-Mejías, M. Luceno, and S. Castroviejo, "Schoenoplectus corymbosus: a tropical old-world sedge (Cyperaceae) discovered in Spain and Morocco," Nordic Journal of Botany, vol. 25, no. 1-2, pp. 70-74, 2007.

[9] E. H. Roalson, "A synopsis of chromosome number variation in the Cyperaceae," The Botanical Review, vol. 74, no. 2, pp. 209-393, 2008.

[10] M. G. L. Hertog, E. J. M. Feskens, D. Kromhout et al., "Dietary antioxidant flavonoids and risk of coronary heart disease: The Zutphen Elderly study," The Lancet, vol. 342, no. 8878, pp. 1007-1011, 1993.

[11] A. Moure, J. M. Cruz, D. Franco et al., "Natural antioxidants from residual sources," Food Chemistry, vol. 72, no. 2, pp. 145-171, 2001.

[12] P. C. H. Holiman, M. G. L. Hertog, and M. B. Katan, "Analysis and health effects of flavonoids," Food Chemistry, vol. 57, no. 1, pp. 43-46, 1996.

[13] A. S. Meyer, M. Heinonen, and E. N. Frankel, "Antioxidant interactions of catechin, cyanidin, caffeic acid, quercetin, and ellagic acid on human LDL oxidation," Food Chemistry, vol. 61, no. 1-2, pp. 71-75, 1998.

[14] E. J. Hunt, C. E. Lester, E. A. Lester, and R. L. Tackett, "Effect of St. John's wort on free radical production," Life Sciences, vol. 69, no. 2, pp. 181-190, 2001.

[15] I. O. Kibwage, J. Mwangi, and G. Thoithi, "Quality control of herbal medicines," East and Central African Journal of Pharmaceutical Sciences, vol. 8, no. 2, pp. 27-30, 2005.

[16] K. A. Hammer, C. F. Carson, and T. V. Riley, "Antimicrobial activity of essential oils and other plant extracts," Journal of Applied Microbiology, vol. 86, no. 6, pp. 985-990, 1999.

[17] I. B. Suffredini, H. S. Sader, A. G. Gonçalves et al., "Screening of antibacterial extracts from plants native to the Brazilian amazon rain forest and atlantic forest," Brazilian Journal of Medical and Biological Research, vol. 37, no. 3, pp. 379-384, 2004.

[18] A. Hassan and H. Ullah, "Antibacterial and antifungal activities of the medicinal plant veronica biloba," Journal of Chemistry, vol. 2019, 2019.

[19] R. A. Hetty Manurung, R. A. Nugroho, Y. Puspita Sari, R. Chernovita, and Auliana, "Phytochemical analysis and antioxidant activity of leaves extracts of endemic plant jahe balikpapan (etlingera balikpapanensis A.D. Poulsen)," International Journal of Scientific \& Technology Research, vol. 8, no. 9, 2019.

[20] M. Labiad, H. Harhar, A. Ghanimi, and M. Tabyaoui, "Phytochemical screening and antioxidant activity of Moroccan thymus satureioides extracts," Journal of Materials and Environmental Sciences, vol. 8, no. 6, pp. 2132-2139, 2017.

[21] T. H. A. Alabri, A. H. S. Al Musalami, M. A. Hossain, A. M. Weli, and Q. Al-Riyami, "Comparative study of phytochemical screening, antioxidant and antimicrobial capacities of fresh and dry leaves crude plant extracts of Datura metel L," Journal of King Saud University-Science, vol. 26, no. 3, pp. 237-243, 2014.

[22] R. Oonsivilai, M. G. Ferruzzi, and S. Ningsanond, "Antioxidant activity and cytotoxicity of rang chuet (Thunbergia laurifolia lindl.) extracts," Asian Journal of Food and AgroIndustry, vol. 1, no. 2, pp. 116-128, 2008.

[23] V. L. Singleton and J. A. Rossi, "Colorimetry of total phenolics with phosphomolybdic-phosphotungstic acid reagents," 
American Journal of Enology and Viticulture, vol. 16, no. 3, pp. 144-158, 1965.

[24] E. Köksal and İ. Gülçin, "Antioxidant activity of cauliflower (Brassica oleracea L.)," Turkish Journal of Agriculture and Forestry, vol. 32, no. 1, pp. 65-78, 2008.

[25] M. A. Hossain, M. D. Shah, C. Gnanaraj, and M. Iqbal, "In vitro total phenolics, flavonoids contents and antioxidant activity of essential oil, various organic extracts from the leaves of tropical medicinal plant Tetrastigma from Sabah," Asian Pacific Journal of Tropical Medicine, vol. 4, no. 9, pp. 717-721, 2011.

[26] S. D. Jacinto, "Determining the antioxidant property of plant extracts: a laboratory exercise," Asian Journal of Biology Education, vol. 5, pp. 22-25, 2011.

[27] G. Marinova and V. Batchvarov, "Evaluation of the methods for determination of the free radical scavenging activity by DPPH," Bulgarian Journal of Agricultural Science, vol. 17, no. 1, pp. 11-24, 2011.

[28] A. Hassan, H. Ullah, and M. Israr, "The antioxidant activity and phytochemical analysis of medicinal plant veronica biloba," Letter In Applied NanoBioscience, vol. 8, no. 4, pp. 732-738, 2019.

[29] G. Rehman, M. Hamayun, A. Iqbal et al., "In vitro antidiabetic effects and antioxidant potential of Cassia nemophila pods," BioMed Research International, vol. 2018, Article ID 1824790, 6 pages, 2018.

[30] A. Khan, G. Jan, A. Khan, F. Gul Jan, A. Bahadur, and M. Danish, "In vitro antioxidant and antimicrobial activities of Ephedra gerardiana (root and stem) crude extract and fractions," Evidence-Based Complementary and Alternative Medicine, vol. 2017, Article ID 4040254, 6 pages, 2017.

[31] N. Savithramma, M. L. Rao, and D. Suhrulatha, "Screening of medicinal plants for secondary metabolites," Middle-East Journal of Scientific Research, vol. 8, no. 3, pp. 579-584, 2011.

[32] K. Chatoui, A. Talbaoui, M. Aneb et al., "Phytochemical screening, antioxidant and antibacterial activity of Lepidium sativum seeds from Morocco," Journal of Materials and Environmental Science, vol. 7, no. 8, pp. 2938-2946, 2016.

[33] L. El Hattabi, A. Talbaoui, S. Amzazi et al., "Chemical composition and antibacterial activity of three essential oils from south of Morocco (Thymus satureoides, Thymus vulgaris and Chamaelum nobilis)," Journal of Materials and Environmental Science, vol. 7, no. 9, pp. 3110-3117, 2016.

[34] D. T. Gordon, D. Stoops, and V. Ratliff, Dietary Fiber and Mineral Nutrition, Eagan Press, Eagan, MN, USA, 1995.

[35] M. A. Sanjoaquin, P. N. Appleby, E. A. Spencer, and T. J. Key, "Nutrition and lifestyle in relation to bowel movement frequency: a cross-sectional study of 20630 men and women in EPIC-Oxford," Public Health Nutrition, vol. 7, no. 1, pp. 77-83, 2004.

[36] D. L. Topping and P. M. Clifton, "Short-chain fatty acids and human colonic function: roles of resistant starch and nonstarch polysaccharides," Physiological Reviews, vol. 81, no. 3, pp. 1031-1064, 2001.

[37] T. Lu, "Potential health benefits and problems associated with antinutrients in foods," Food Research International, vol. 26, no. 2, pp. 131-148, 1993.

[38] C. P'ei and S. Chen, "Verbenaceae," Flora Reipublicae Popularis Sinicae, vol. 65, no. 1, pp. 1-49, 1982.

[39] J. Sharifi-Rad, "Herbal antibiotics: moving back into the mainstream as an alternative for superbugs," Cellular and Molecular Biology, vol. 62, no. 9, pp. 1-2, 2016.

[40] R. Alghazeer, H. El-Saltani, N. Saleh, A. Al-Najjar, and F. Hebail, "Antioxidant and antimicrobial properties of five medicinal Libyan plants extracts," Natural Science, vol. 4, no. 5, pp. 324-335, 2012.

[41] H. Edziri, M. Mastouri, I. Chéraif, and M. Aouni, "Chemical composition and antibacterial, antifungal and antioxidant activities of the flower oil of Retama raetam (Forssk) Webb from Tunisia," Natural Product Research, vol. 24, no. 9, pp. 789-796, 2010.

[42] Y. Sato, H. Shibata, T. Arai et al., "Variation in synergistic activity by flavone and its related compounds on the increased susceptibility of various strains of methicillin-resistant Staphylococcus aureus to $\beta$-lactam antibiotics," International Journal of Antimicrobial Agents, vol. 24, no. 3, pp. 226-233, 2004.

[43] T. P. T. Cushnie and A. J. Lamb, "Antimicrobial activity of flavonoids," International Journal of Antimicrobial Agents, vol. 26, no. 5, pp. 343-356, 2005.

[44] M. M. Cowan, "Plant products as antimicrobial agents," Clinical Microbiology Reviews, vol. 12, no. 4, pp. 564-582, 1999.

[45] B. Mamtha, K. Kavitha, K. K. Srinivasan, and P. G. Shivananda, "An in vitro study of the effect of Centella asiatica [Indian pennywort] on enteric pathogens," Indian Journal of Pharmacology, vol. 36, no. 1, p. 41, 2004.

[46] R. F. Epand, P. B. Savage, and R. M. Epand, "Bacterial lipid composition and the antimicrobial efficacy of cationic steroid compounds (Ceragenins)," Biochimica et Biophysica Acta (BBA)-Biomembranes, vol. 1768, no. 10, pp. 2500-2509, 2007.

[47] R. M. Zablotowicz, R. E. Hoagland, and S. C. Wagner, "Effect of saponins on the growth and activity of rhizosphere bacteria," in Saponins Used in Food and Agriculture, pp. 83-95, Springer, Berlin, Germany, 1996.

[48] N. E. Hernández, M. Tereschuk, and L. Abdala, "Antimicrobial activity of flavonoids in medicinal plants from Tafı del Valle (Tucuman, Argentina)," Journal of Ethnopharmacology, vol. 73, no. 1-2, pp. 317-322, 2000

[49] F. Shahidi and P. Ambigaipalan, "Phenolics and polyphenolics in foods, beverages and spices: antioxidant activity and health effects-a review," Journal of Functional Foods, vol. 18, pp. 820-897, 2015.

[50] M. S. Brewer, "Natural antioxidants: sources, compounds, mechanisms of action, and potential applications," Comprehensive Reviews in Food Science and Food Safety, vol. 10, no. 4, pp. 221-247, 2011.

[51] R.-M. Han, J.-P. Zhang, and L. H. Skibsted, "Reaction dynamics of flavonoids and carotenoids as antioxidants," Molecules, vol. 17, no. 2, pp. 2140-2160, 2012.

[52] K. Wolfe, X. Wu, and R. H. Liu, "Antioxidant activity of apple peels," Journal of Agricultural and Food Chemistry, vol. 51, no. 3, pp. 609-614, 2003.

[53] V. Koleckar, K. Kubikova, Z. Rehakova et al., "Condensed and hydrolysable tannins as antioxidants influencing the health," Mini-Reviews in Medicinal Chemistry, vol. 8, no. 5, pp. 436447, 2008.

[54] A. Fernández-Agulló, E. Pereira, M. S. Freire et al., "Influence of solvent on the antioxidant and antimicrobial properties of walnut (Juglans regia L.) green husk extracts," Industrial Crops and Products, vol. 42, pp. 126-132, 2013.

[55] M. H. H. Roby, M. A. Sarhan, K. A.-H. Selim, and K. I. Khalel, "Evaluation of antioxidant activity, total phenols and phenolic compounds in thyme (Thymus vulgaris L.), sage (Salvia officinalis L.), and marjoram (Origanum majorana L.) extracts," Industrial Crops and Products, vol. 43, pp. 827-831, 2013. 
[56] T. O. Elufioye, C. G. Chinaka, and A. O. Oyedeji, "Antioxidant and anticholinesterase activities of macrosphyra longistyla (DC) hiern relevant in the management of alzheimer's disease," Antioxidants, vol. 8, no. 9, p. 400, 2019.

[57] W. Wan Rosli, S. N. Haffizah, and H. R. Nurraihana, "Antioxidative and scavenging Properties of polyphenolic rich-fraction of cornlettes (young Zea mays)," International Journal of Recent Technology and Engineering, vol. 7, p. 5, 2018.

[58] R. M. S. Al-Muniri and M. A. Hossain, "Evaluation of antioxidant and cytotoxic activities of different extracts of folk medicinal plant Hapllophyllum tuberculatum," Egyptian Journal of Basic and Applied Sciences, vol. 4, no. 2, pp. 101-106, 2017.

[59] A. Luo and Y. Fan, "Antioxidant activities of various fractions extracted from Astragalus," African Journal of Pharmacy and Pharmacology, vol. 5, no. 10, pp. 1297-1302, 2011.

[60] M. Afolayan et al., "In vitro antioxidant, antimicrobial and phytochemical properties of wild banana [Ensete gilletii (EAJ DE Wildman)] seeds extract," International Journal of Advanced Chemistry, vol. 2, no. 2, pp. 59-61, 2014.

[61] Z. S. S. Al-Hashemi and M. A. Hossain, "Biological activities of different neem leaf crude extracts used locally in Ayurvedic medicine," Pacific Science Review A: Natural Science and Engineering, vol. 18, no. 2, pp. 128-131, 2016.

[62] A. Mavi, Z. Terzi, U. Özgen, A. Yildirim, and M. Coşkun, "Antioxidant properties of some medicinal plants: prangos ferulacea (Apiaceae), sedum sempervivoides (Crassulaceae), Malva neglecta (malvaceae), Cruciata taurica (Rubiaceae), Rosa pimpinellifolia (Rosaceae), Galium verum subsp. verum (Rubiaceae), Urtica dioica (urticaceae)," Biological \& Pharmaceutical Bulletin, vol. 27, no. 5, pp. 702-705, 2004.

[63] O. M. Mosquera, Y. M. Correa, D. C. Buitrago, and J. Niño, "Antioxidant activity of twenty five plants from Colombian biodiversity," Memórias Do Instituto Oswaldo Cruz, vol. 102, no. 5, pp. 631-634, 2007.

[64] N. P. Manandhar, Plants and People of Nepal, Timber Press, Portland, OR, USA, 2002.

[65] S. Koduru, D. S. Grierson, and A. J. Afolayan, "Antimicrobial activity of Solanum aculeastrum," Pharmaceutical Biology, vol. 44, no. 4, pp. 283-286, 2006.

[66] M. H. Alma, A. Mavi, A. Yildirim, M. Digrak, and T. Hirata, "Screening chemical composition and in vitro antioxidant and antimicrobial activities of the essential oils from Origanum syriacum L. growing in Turkey," Biological \& Pharmaceutical Bulletin, vol. 26, no. 12, pp. 1725-1729, 2003.

[67] R. Govindarajan, S. Rastogi, M. Vijayakumar et al., "Studies on the antioxidant activities of Desmodium gangeticum," Biological \& Pharmaceutical Bulletin, vol. 26, no. 10, pp. 1424-1427, 2003.

[68] H. De Lencastre, D. Oliveira, and A. Tomasz, "Antibiotic resistant Staphylococcus aureus: a paradigm of adaptive power," Current Opinion in Microbiology, vol. 10, no. 5, pp. 428-435, 2007.

[69] N. Mishra, T. Prasad, N. Sharma et al., "Pathogenicity and drug resistance inCandida albicansand other yeast species," Acta microbiologica et immunologica Hungarica, vol. 54, no. 3, pp. 201-235, 2007.

[70] P. Molyneux, "The use of the stable free radical diphenylpicrylhydrazyl (DPPH) for estimating antioxidant activity," Songklanakarin Journal of Science and Technology, vol. 26, no. 2, pp. 211-219, 2004.

[71] S. R. Kanatt, A. Siddiqui, and S. P. Chawla, "Antioxidant/ antimicrobial potential of emblica officinalis gaertn and its application as a natural additive for shelf life extension of minced chicken meat," Biointerface Research in Applied Chemistry, vol. 8, no. 4, pp. 3344-3350, 2018.

[72] Z. Kanwal, T. U. Rahman, M. A. Zeb, and M. Sajid, "Antioxidant, $\alpha$-amylase inhibitory and antiglycation activity of berberis royleana roots," Biointerface Research in Applied Chemistry, vol. 8, no. 6, pp. 3725-3728, 2018

[73] G. Bahramian, L. Golestan, and K. Khosravi-Darani, “Antimicrobial and antioxidant effect of nanoliposomes containing zataria multiflora boiss essential oil on the rainbow trout fillets during refrigeration," Biointerface Research in Applied Chemistry, vol. 8, no. 5, pp. 3505-3513, 2018.

[74] L. Bravo, "Polyphenols: chemistry, dietary sources, metabolism, and nutritional significance," Nutrition Reviews, vol. 56, no. 11, pp. 317-333, 1998.

[75] G. Agati, E. Azzarello, S. Pollastri, and M. Tattini, "Flavonoids as antioxidants in plants: location and functional significance," Plant Science, vol. 196, pp. 67-76, 2012. 